\title{
Rancang Bangun Timbangan Beras Digital Dengan Tampilan Berat Dan Harga Menggunakan Output Suara
}

\author{
Era Madona ${ }^{1}$, Anton $^{2}$, Dolla $^{3}$ \\ ${ }^{123}$ Jurusan Teknik Elektro Politeknik Negeri Padang \\ emadona38@gmail.com \\ Kampus Politeknik Negeri Padang, Limau Manis Padang
}

\begin{abstract}
Generally, scales on the market still use manual models which often produce a measurement with the inappropriate result because of the accuracy problem or still have trouble with the level of precision. Furthermore, other measuring instruments are also only pendulum balances or analog scales whose output measurement results are only indicated by the pointer. The results of reading each person have different measurement results. In addition to requiring energy and a long time, the manual weighing process also has a negative impact that can harm consumers where the trader in the market usually cheats in trading. To address this problem, a digital rice weighing device is designed that is controlled by Arduino Uno by using a load cell sensor that having a capacity of $10 \mathrm{~kg}(1 / 2-2.5$ liters $)$ which provides a change of resistance when there is a pressure. Changes in resistance can change the output voltage of a load cell. The voltage change that is too small so it is amplified using the HX711 and will convert it to digital in units of weight per liter. The level heavy of rice is calculated at prices corresponding to rice selected through pushbutton. The calculation results are displayed on the LCD if the rice is not enough 1 liter so the price and weight will not be displayed on the LCD. The output sound of Mini Df will mention the price based on the type of rice.
\end{abstract}

Keywords: Arduino uno, Loadcell sensors, HX711, Pushbutton, LCD, Df Mini Player.

\begin{abstract}
Abstrak-Timbangan di pasaran umumnya masih menggunakan timbangan manual yang sering kali masih menghasilkan pengukuran yang tidak teliti dikarenakan tidak adanya akurasi dan tingkat presisi. Selain itu alat ukur yang lain juga hanya sebuah neraca bandul atau timbangan analog yang output hasil pengukurannya hanya ditunjukkan oleh jarum penunjuk. Hasil pembacaan masing-masing orang memiliki hasil pengukuran yang berbeda. Selain membutuhkan tenaga dan waktu yang lama proses penimbangan manual juga memiliki dampak negatif yang dapat merugikan konsumen di mana pedangang di pasar biasanya melakukan kecurangan dalam berdagang. Untuk menyelesaikan permasalahan tersebut, maka dari itu dirancang sebuah alat timbangan beras digital, timbangan ini dikendalikan oleh arduino uno dengan menggunakan sensor load cell berkapasitas 10kg (1/2- 2,5 liter) yang memberikan perubahan resistansi apabila terdapat regangan akibat adanya beban. Perubahan resistansi dapat diubah menjadi perubahan tegangan. Perubahan tegangan terlalu kecil sehingga dikuatkan menggunakan HX711 dan akan mengubahnya menjadi digital dalam satuan berat per liter. Satuan berat dikalkulasikan dengan harga yang sesuai dengan beras yang dipilih melalui pushbutton. Hasil kalkulasi ditampilkan pada display LCD apabila beras belum mencukupi 1 liter maka tampilan harga dan berat tidak akan di tampilan di LCD dan begitu juga dengan output suara berupa Df Mini yang akan menyebutkan harga dari jenis beras tersebut
\end{abstract}

Kata kunci:Arduino uno, Sensor Loadcell, HX711, Pushbutton, LCD, Df Player Mini.

(C) 2018 Elektron Jurnal Ilmiah

\section{PENDAHULUAN}

Karyawan yang bekerja di perkantoran mempunyai Timbangan di pasaran umumnya masih menggunakan timbangan manual yang sering kali masih menghasilkan pengukuran yang tidak teliti dikarenakan tidak adanya akurasi dan tingkat presisi. Selain itu alat ukur yang lain juga hanya sebuah neraca bandul atau timbangan analog yang output hasil pengukurannya hanya ditunjukkan oleh jarum penunjuk. Hasil pengukuran yang ditunjukkan oleh jarum penunjuk tidak menghasilkan hasil pembacaan yang tepat. Hasil pembacaan masing-masing orang memiliki hasil pengukuran yang berbeda. Selain membutuhkan tenaga dan waktu yang lama proses penimbangan manual juga memiliki dampak negative yang dapat merugikan konsumen di mana pedangang di pasar biasanya melakukan kecurangan dalam berdagang. Orang-orang yang tidak bertanggung jawab biasanya menggunakan alat timbangan yang tidak sesuai dengan takaran yang sebenarnya, pedagang biasanya merubah sistem kerja dari timbangan 
tersebut sehingga dapat merugikan konsumen. Alat timbangan menggunakan load cell sebagai sensor berat dan output menggunakan LCD dan suara telah dibuat sebelumnya Nika Wahyuni [1]. Maka dari kekurangan alat sebelumnya penulis membuat pengembangan alat dengan cara menimbang berat beras per liter pada saat beras diletakan di wadah timbangan apabila telah mencukupi takaran liter maka tampilan pada LCD akan muncul dengan tampilan harga dan jenis beras, jika kurang dari takaran liter maka tampilan pada LCD tidak akan muncul berdasarkan jenis beras yang di pilih menggunakan pushbutton dan selain ditampilkan di LCD penulis juga menggunakan output suara untuk mengetahui harga yang harus dibayar. Pedagang tidak perlu lagi untuk mengkalkulasikan harga menggunakan kalkulator tiap kali ingin menimbang beras, penulis juga menambahkan output suara menggunakan DF Mini Player untuk mengetahui harga yang harus dibayar. Berdasarkan uraian masalah diatas maka penulis membuat sebuah timbangan beras digital dengan tampilan berat dan harga menggunakan output suara. Dengan dibuatnya alat ini dapat mengatasi permasalahan sebelumnya.

\section{METODE PENELITIAN}

\section{A.Perancangan Sistim dan Blok Diagram}

Perancangan sistem keseluruhan alat ini tersusun atas tiga bagian penting yang saling terhubung satu sama lain yaitu bagian hardware, software dan mekanik. Ketiga bagian ini saling berkaitan agar menjadi sebuah sistim yang bisa digunakan. Blok diagram sistim secara keseluruhan diperlihatkan oleh gambar 1 dibawah ini.

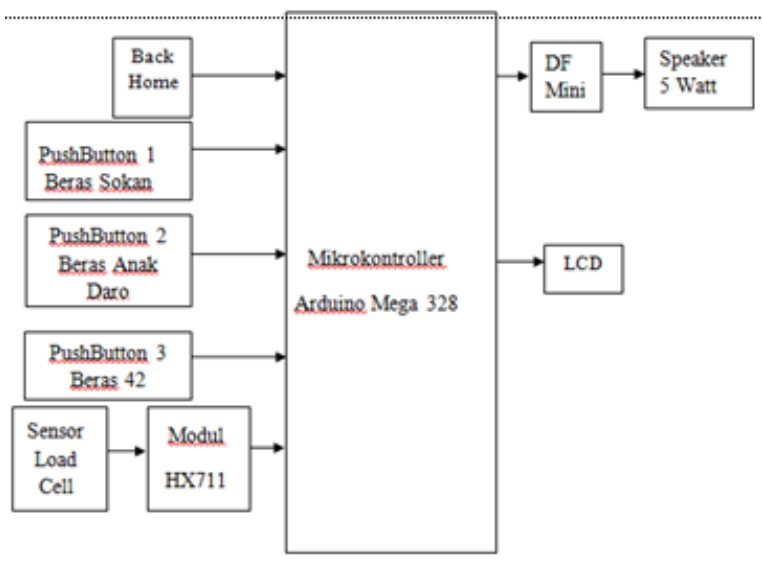

Gambar 1. Blok Diagram Sistem

Pada saat konsumen membeli beras, beras yang dipilih oleh konsumen akan ditimbang di wadah timbangan oleh penjual lalu tekan salah satu tombol jenis beras yang ditimbang. Selanjutnya loadcell akan mengukur berat dari beras yang,kemudian mikrokontroler Atmega 328 akan menjadi satuan berat per liter. Dan untuk output ada dua keluaran yaitu tampilan display LCD yang akan menampilkan berat dan harga dari beras dan DF Mini Player sebagai penguat suara yang akan dikeluarkan dalam bentuk kalimat berupa harga dari beras oleh speaker. Jika penjual ingin meggganti pemilihan beras tekan tombol Back Home.

\section{B. Perancangan Perangkat Keras (Hardware)}

Hardware pada sistim ini terdiri dari power supply, Loadcell, Modul penguat $\mathrm{Hx} 711$, Pushbutton, Atmega 328, LCD 16x2, DF Mini Player dan Speaker 5 watt. Rangkaian alat secara keseluruhan dapat dilihat pada gambar 2 .

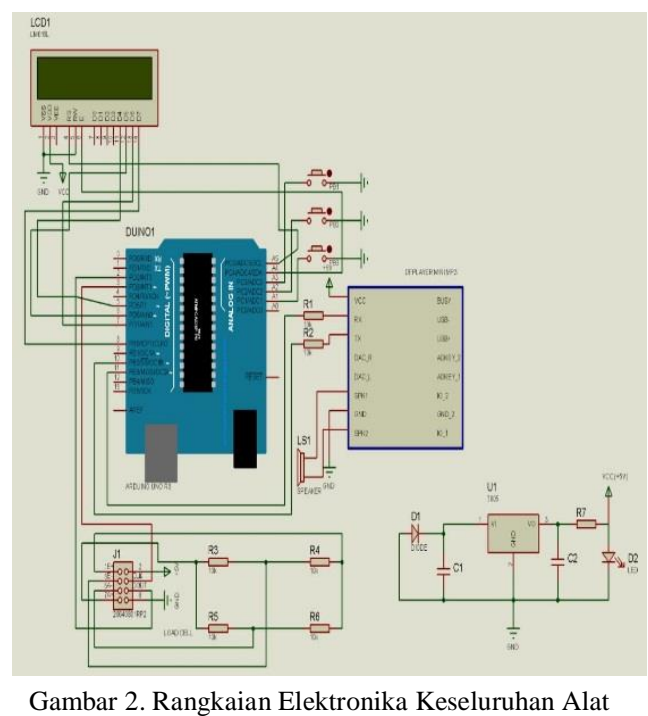

Pada pembuatan alat ini menggunakan power supply penyearah setengah gelombang. Sensor load cell digunakan untuk menghitung berat. Cara kerjanya, sensor ini akan mendeteksi adanya perubahan tekanan yang diakibatkan adanya beban. Perubahan tekanan tersebut akan menyebabkan perubahan resistansi pada jembatan wheatsone yang terdapat pada load cell sehingga terjadi ketidak seimbangan resistansi, akibatnya tegangan keluaran dari jembatan wheatsone tersebut mengalami perubahan yang nantinya akan dibaca oleh Arduino. Namun karena perubahan tegangan tersebut sangat kecil (dalam skala mili volt) sehingga keluaran dari load cell harus terlebih dahulu dikuatkan untuk mencapai nilai dalam bentuk volts. Maka dari itu digunakan modul HX711 yang berfungsi sebagai ADC sekaligus penguat tegangan, dimana keluaran Loadcell terhubung ke input HX711, sedangkan keluaran HX711 terhubung ke mikrokontroler Atmega 328.Push button digunakan untuk kembali ke home untuk pemilihan jenis beras. Modul Audio Player berfungsi untuk membaca data digital dan mengubahnya menjadi audio. Modul Audio yang digunakan adalah Modul DF Mini Player. Pada alat ini DF mini player berguna untuk modul dari output 
suara yang akan dihubungkan ke speaker sebagai audio dari total biaya beban timbangan dalam rupiah.

\section{Perancangan Perangkat Lunak (Software)}

Setelah pembuatan perangkat hardware, langkah selanjutnya yang dilakukan adalah perancangan software. Dalam merancang software ini terlebih dahulu adalah membuat algoritmanya. Algoritma merupakan garis besar jalannya suatu program, salah satu algoritma yang dibuat dalam bentuk flow chart (diagram alir) agar perancangan software mudah dilakukan dengan cepat. Hal ini dapat memperlihatkan secara sederhana dan jelas alur dari program secara keseluruhan yang akan dibuat. Diagram alur ini dirancang untuk rancang bangun timbangan beras dengan tampilan harga dan output suara. Berikut Flow chart dari sistem ini adalah :

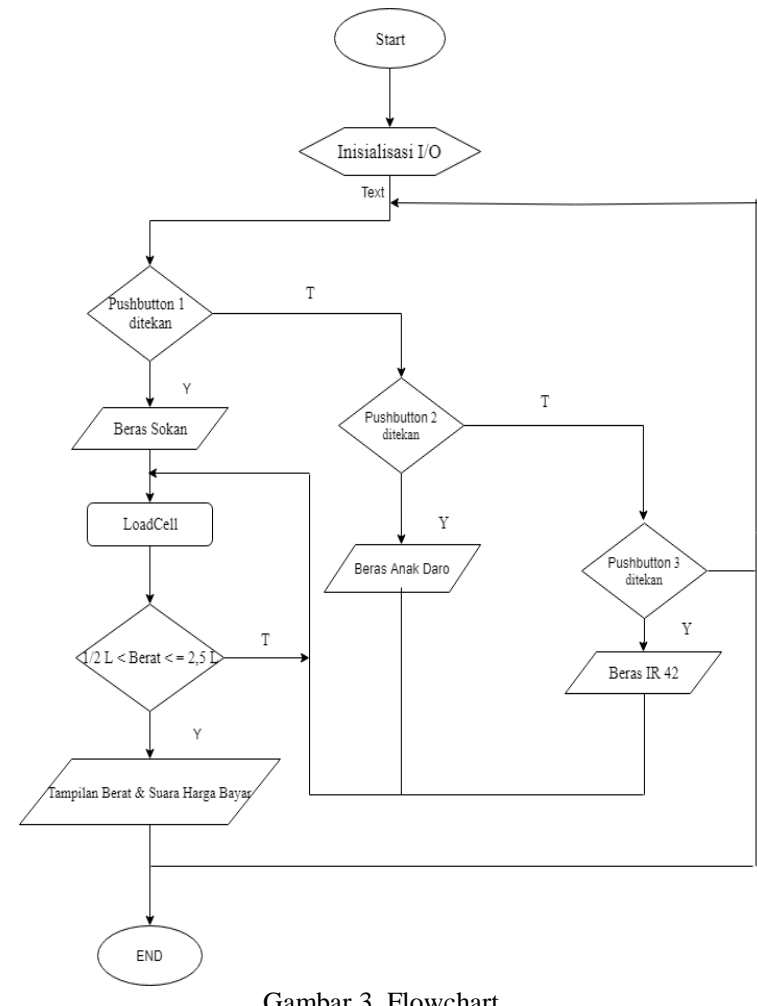

Gambar 3. Flowchart

Penjelasan algoritma program sistem kerja alat pada gambar flowchart diatas dapat diuraikan sebagai berikut:

1. Start akan menginisialisasi hardware yang meliputi Load cell, LCD dan speaker.

2. Proses dilanjutkan pemilihan jenis beras yang ditimbang dan akan dilanjutkan dengan proses pembacaan sensor, kemuadian setelah itu proses perhitungan akumulasi harga secara otomatis berdasarkan berat beras dengan sensor (load cell) mendeteksi keberadaan beras yang terletak diatasnya.

3. Selanjutnya, perhitungan berat dan harga ditampilkan pada LCD dan keluaran output suara pada Speaker sebagai audio dari total biaya beban timbangan dalam rupiah.

4. Stop akan mengakhiri sistem

\section{Perancangan Mekanik}

Pada perancangan mekanik ini bertujuan untuk mengatur tata letak komponen dan juga untuk memposisikan penampang timbangan agar benda yang ditimbang berada tepat pada posisi sensor. Timbangan beras ini dibangun dengan ukuran box panjang $300 \mathrm{~mm}$, lebar $300 \mathrm{~mm}$ dan tinggi $100 \mathrm{~mm}$. Sedangkan untuk kedudukan timbangan $250 \mathrm{~mm}$ x $200 \mathrm{~mm}$. Perancangan timbangan beras dapat dilihat pada gambar di bawah ini.

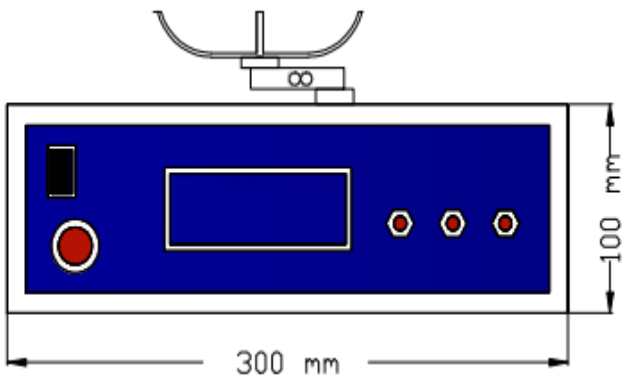

Gambar 4. Tampak Depan Alat

Pada bagian box timbangan, dibagian dalam terdapat power supply, arduino dan penguat instrument. Sedangkan bagian luar tertempel pada dinding box LCD, speaker dan saklar on/off. Pada bagian atas box terpasang load cell langsung dengan kedudukan timbangan.

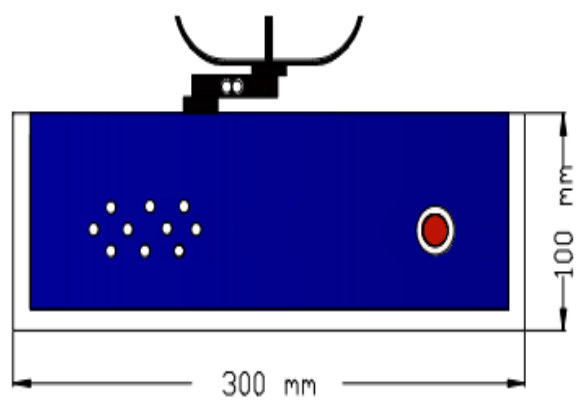

III. HASIL DAN PEMBAHASAN

Pengujian alat ini dilakukan untuk mengetahui apakah alat yang dibuat telah sesuai dengan yang diharapkan. Pengujian juga dilakukan untuk mengetahui hasil dari pengukuran pada masingmasing blok rangkaian yang terdapat pada alat. Untuk melakukan pengujian membutuhkan multimeter dan osiloskop sebagai media pengukurannya. Berikut langkah-langkah dan pokok 
pembahasan yang akan di lakukan dalam pangujian sebagai berikut :

1 Pengujiandan analisa sensor Load Cell dan Pengujian HX711

2 Pengujian dan Analisa Alat Secara Keseluruhan

\section{A. Pengujian dan Analisa Load Cell}

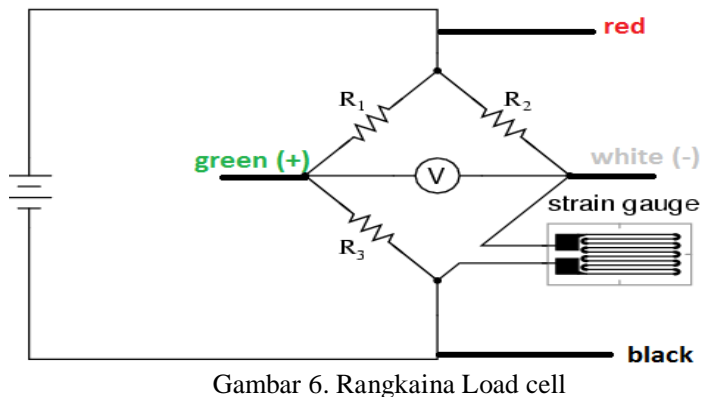

Pengujian pada Loadcell harus diperhatikan dengan teliti pada keadaan awal (tanpa beban), keluaran dari loadcell harus 0 Volt yang berarti dalam posisi seimbang, namun ketika loadcell diberi beban terjadi perubahan pada nilai resistansi yang mana prinsip kerja loadcell berdasarkan pada jembatan Wheastone.

Tabel 1. hasil pegukuran load cell terhadap beban

$\begin{array}{cccc}\text { Jenis } & \text { Berat / Liter } & \text { Berat / Liter } & \text { Tegangan } \\ \text { Beras } & \text { Timbangan } & \text { Timbangan } & (\mathrm{mV})\end{array}$

\begin{tabular}{|c|c|c|c|}
\hline \multirow{8}{*}{$\begin{array}{l}\text { Beras } \\
\text { Sokan }\end{array}$} & $1 / 2$ Liter $=0,4 \mathrm{Kg}$ & $0,48 \mathrm{Kg}$ & 0,1 \\
\hline & 1 Liter $=0,8 \mathrm{Kg}$ & $0,94 \mathrm{Kg}$ & 0,3 \\
\hline & 1,5 Liter $=1,2 \mathrm{Kg}$ & $1,31 \mathrm{Kg}$ & 0,5 \\
\hline & 2 Liter $=1,6 \mathrm{Kg}$ & $1,67 \mathrm{Kg}$ & 0,6 \\
\hline & 2,5 Liter $=2 \mathrm{Kg}$ & $1,91 \mathrm{Kg}$ & 0,8 \\
\hline & 3 Liter $=2,4 \mathrm{Kg}$ & $2,37 \mathrm{Kg}$ & 1,0 \\
\hline & 3,5 Liter $=2,8 \mathrm{Kg}$ & $2,75 \mathrm{Kg}$ & 1,1 \\
\hline & 4 Liter $=3,2 \mathrm{Kg}$ & $3,21 \mathrm{Kg}$ & 1,3 \\
\hline \multirow{8}{*}{$\begin{array}{l}\text { Beras } \\
\text { Anak } \\
\text { Daro, }\end{array}$} & $1 / 2$ Liter $=0,4 \mathrm{Kg}$ & $0,59 \mathrm{Kg}$ & 0,1 \\
\hline & 1 Liter $=0,8 \mathrm{Kg}$ & $0,95 \mathrm{Kg}$ & 0,3 \\
\hline & 1,5 Liter $=1,2 \mathrm{Kg}$ & $1,32 \mathrm{Kg}$ & 0,5 \\
\hline & 2 Liter $=1,6 \mathrm{Kg}$ & $1,68 \mathrm{Kg}$ & 0,6 \\
\hline & 2,5 Liter $=2 \mathrm{Kg}$ & $2,03 \mathrm{Kg}$ & 0,8 \\
\hline & 3 Liter $=2,4 \mathrm{Kg}$ & $2,38 \mathrm{Kg}$ & 1,0 \\
\hline & 3,5 Liter $=2,8 \mathrm{Kg}$ & $2,77 \mathrm{Kg}$ & 1,1 \\
\hline & 4 Liter $=3,2 \mathrm{Kg}$ & $0,60 \mathrm{Kg}$ & 1,3 \\
\hline Beras IR & $1 / 2$ Liter $=0,4 \mathrm{Kg}$ & $0,60 \mathrm{Kg}$ & 0,1 \\
\hline 42 & 1 Liter $=0,8 \mathrm{Kg}$ & $1,84 \mathrm{Kg}$ & 0,3 \\
\hline
\end{tabular}

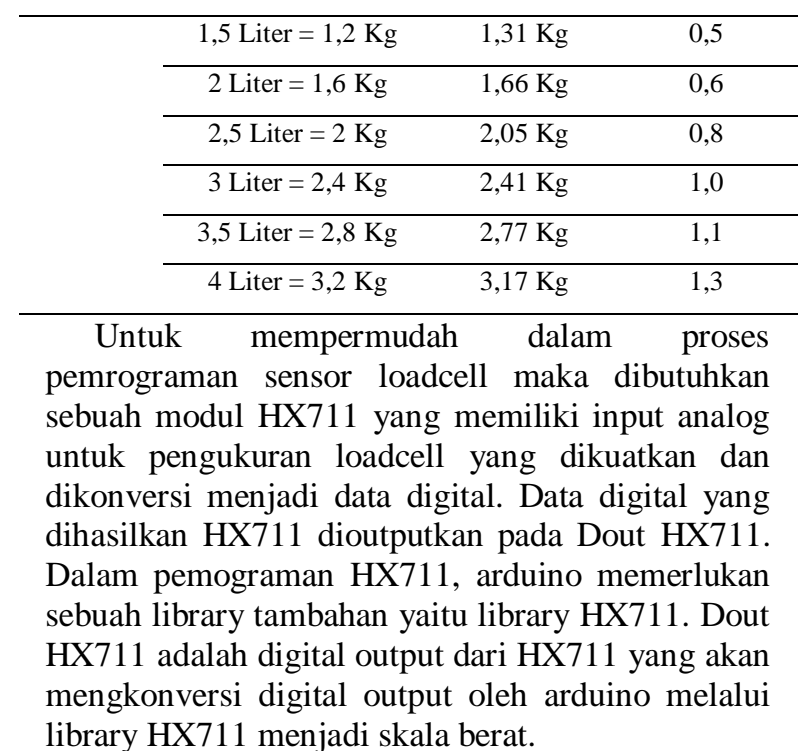

\section{B. Pengujian dan Analisa Alat Secara Keseluruhan}

Pengujian alat secara keseluruhan bertujuan untuk mengetahui alat yang telah dibuat dapat berjalan secara baik dan benar antara software dan hardware. Untuk pengujian load cell telah dilakukan dengan memberikan beban yang berbeda kemudian mengukur tegangan outputnya. Tegangan output dari load cell terlalu kecil maka dibutuhkan modul HX711 yang berperan sebagai penguat sekaligus pengkonverter data analog dari load cell menjadi data digital. Untuk pemograman load cell dilakukan dengan menggunakan library dari modul HX711 pada arduino yang mana digital output akan dikonversi oleh arduino melalui library HX711 menjadi skala berat. Pengujian alat secara keseluruhan ini dilakukan dengan membandingkan data saat beban di timbang menggunakan alat yang dibuat dengan menggunakan data sebenarnya dari timbangan biasa. Sedangkan untuk tampilan harga sesuai dengan keinginan yaitu untuk berat $1 / 2$ liter bernilai $0,4 \mathrm{~kg} 1$ liter bernilai $0,8 \mathrm{~kg}, 1,5$ liter bernilai $1,2 \mathrm{~kg}, 2$ liter bernilai $1,6 \mathrm{~kg}, 2,5$ liter bernilai $2 \mathrm{~kg}, 3$ liter bernilai 2,4 kg, dan 3,5 liter bernilai $2,8 \mathrm{~kg}$ dan terakhir 4 liter bernilai $3,2 \mathrm{~kg}$, Hal ini terjadi dikarenakan antara berat dan harga telah dikalkulasikan langsung didalam program. Untuk output suaranya, setiap pertambahan berat dari $1 / 2$ hingga 4 liter maka akan terdengar suara harga berdasarkan jenis beras yang dipilih.

\section{KESIMPULAN}

1. Alat ini bisa menimbang berat beras dengan satuan per liter, pada LCD dapat ditampilkan jenis, berat dan harga.

2. Berdasarkan hasil pengukuran loadcell terhadap beban didapatkan hasil error berat per liter rata-rata $17 \%$. 
3. Pada alat ini pushbutton dapat berfungsi sebagai sarana pemilihan beras.

4. Penggunaan DF Mini Player akan mengeluarkan suara harga per liter

\section{REFERENSI}

[1] MIrfan. Mesin Penyaji Beras Secara Digital. Jurnal Ilmiah ILKOM Volume 8 Nomor 2 (Agustus 2016). hal 126-131

[2] Ahmad Nur Aliyanto, Muhammad Saleh, Aryanto Hartoyo. Perancangan Sistem Timbangan Digital Berbasis Arduino Mega 2560. Jurlah Ilmiah Untan.

[3] Alhamidi, Rini Asmara. Rancang Bangun Timbangan Badan Output Suara Berbasis Arduino Uno R3. Jurnal Sains Dan Informatika Research of Science and Informatic V3.I2 (142-152).

[4] Tri Hamdani Agung Cahyono, Eko Agus Suprayitno. Alat Ukur Berat Badan, Tinggi Badan Dan Suhu Badan Di Posyandu Berbasis Android. ELINVO(Electronics, Informatics, and Vocational Education), May 2018,3(1), 31-38

[5] Edwar Frendi Yandra, Boni pahlanop Lapanporo Muh. Ishak Jumarang. Rancang Bangun Timbangan Digital Berbasis Sensor Beban $5 \mathrm{Kg}$ Menggunakan Mikrokontroler Atmega328. POSITRON, Vol. VI, No. 1 (2016), Hal. 23 - 28

[6] Trisya Septiana, Zaini. Perancangan dan Implementasi Sistem Monitoring Beban dan Kecepatan Kendaraan Menggunakan Teknologi Weigh in Motion. Jurnal Nasional Teknik Elektro, Vol. 7, No. 1, Maret 2018. Hal 60-67

[7] Vera Wati, N. 2014. "Rancang Bangun Timbangan Digital dengan Tampilan Harga Menggunakan LCD”. Tugas Akhir, Padang : Teknik Elektronika Politeknik Negeri Padang.

[8] Wahyuni, Nika. 2014. "Rancang Bangun Timbangan Digital dengan Tampilan Harga dan Output Suara". Tugas Akhir, Padang :Teknik Elektronika Politeknik Negeri Padang. 